\title{
5
}

\section{The Contribution of Not-for-Profits to Democratic Process}

\author{
Tessa Boyd-Caine
}

\section{Introduction}

Community organisations are often identified first and foremost with social services such as those for people experiencing homelessness or those needing emergency relief or financial counselling. Yet not-forprofit (NFP) organisations play a critical role within civil society more broadly, enabling democratic participation in myriad ways. These roles are not necessarily divergent, but they are reflective of the range of relationships and processes by which NFPs contribute to society. This chapter explores some of these relationships and processes and the contribution to civil society that NFP organisations make through them. It argues that a strong and independent civil society balances out the power and control that can otherwise be centralised in democratic governance and decision-making, enabling the participation of people and communities in the decisions made about them and facilitating leadership from and participation by communities, including people affected by poverty, inequality and injustice.

Beyond the ever evolving understanding of who and what civil society is, it is important to understand the relationship between civil society broadly and its component parts, such as non-governmental, non-profit organisations, as well as the actors with whom civil society 
engages, such as governments and the private sector. At its heart, the value offered by NFPs to democratic process is in these organisations' contribution to civil society and through it to public life, including through policy ideas, leadership and social change.

This chapter takes as its central framework five themes developed by the Australian Council of Social Service (ACOSS) to understand the contribution of NFPs to democratic process. ${ }^{1}$ Drawing on examples taken from ACOSS in recent years, these themes are contextualised within current policy and public debate to show how NFPs can contribute to democratic process and where that contribution can be constrained or ineffectual. It also draws on comparative examples from the United States, based on work undertaken during a Fulbright Professional Scholarship in Nonprofit Leadership in 2014, to consider alternative ways in which the NFP sector could engage with such processes.

\section{Sharing power and control: Our role in governance and decision-making}

Understanding and challenging the distribution of power in society, including its consequences for people's sense of control and agency, are core components of the contribution made by a strong and independent civil society. Key elements of this contribution include the capacity to reflect on the concentration of power in Australian society, and developing a range of strategies to shift and share power. We need to know and name where power is concentrated, to claim the right to share power in processes that impact on people less powerful and to challenge the status quo, proposing big new ideas and expressing our dissent. Some recent examples of the NFP sector's efforts in sharing power with Australian governments are set out below, to consider how effective those efforts have been.

Collaboration between agents with differing degrees of power is a key process through which civil society often works to share power and control. In 2015, for example, in articulating the social and economic challenges of our time, community and business interests were repeatedly framed as divergent. Whether in tax reform,

1 These themes were developed by ACOSS from its Civil Society Forum, held on 25 February 2014 in Sydney. 
industrial relations and employment or climate change, the dominant narrative setting out the case for reform in these areas routinely (and respectively) pits business interests (such as support for tax cuts) as oppositional to community interests (such as increased revenue to support adequate provision of community services). The assumption that business interests in enhanced industrial competitiveness conflict with workers' interests in decent wages presents a similar oppositional view, as does the portrayal of economic growth as a choice over environmental sustainability, health and well-being.

Each of these issues was identified by the National Reform Summit in 2015, which was an effort in collaboration across community, business, industry and union organisations. The summit was an explicit attempt to challenge this repeated framing of dichotomous interests as a barrier to achieving reform in a deliberately non-political process to identify common ground on the social and economic policy challenges facing Australia. The collaboration among sectoral interests - hitherto regarded as opposing - was an achievement in itself; consensus over the reform agenda produced by the summit was an even more important achievement. It was a collaboration that challenged an ageold narrative of conflict rather than coherence in policy proposals from non-governmental actors - a framing that had perpetuated competitive assumptions that one interest must win out over others and that certain interests had more power than others.

Community interests were represented at the summit through ACOSS as the peak body for charities and a voice for people experiencing poverty and inequality, the Australian Youth Affairs Coalition, the Council on the Ageing and National Seniors. This representation ensured that the summit's focus on productivity and participation as economic drivers of growth was grounded in the lived experience of people seeking to access (in the case of young people) or remain involved (in the case of older people) in the labour market.

Given that the perspectives of people locked out of the labour market are often excluded from economic debate, the National Reform Summit demonstrated how collaboration can shift concentrations of power in policy debates. But it was not unique in using collaboration to bring new voices to established debates. Before the Summit, many of the same organisations had come together in the articulation of a set of principles to guide policy on climate change in the interests of economic, as well as environmental, sustainability (Australian 
Climate Roundtable 2015). Separately, ACOSS had also been working in partnership for several years with its peak body counterparts the Business Council of Australia and the Australian Council of Trade Unions (ACTU) on an agenda for 'collaborative action' focused on 'providing employment opportunities for Australians who are disadvantaged in the labour market; and giving employers access to workers who meet their skills needs' (ACOSS et al. 2012a). Beyond the policy gains made in each of these individual efforts, such collaboration speaks to a broader objective to build policy consensus through decision-making processes that better reflect the wide and shared interests of all parts of our society and our economy, in a way that partisan politics finds very hard to do. For ACOSS, ensuring the voice of people experiencing poverty and inequality in Australia is reflected in national policy debates and decision-making alongside the voices of business, industry or organised labour is a core objective of working collaboratively in this way.

Reflecting the voice of people or communities affected by policy debates is a vital role played by the NFP sector as it seeks to ensure that the governance and decision-making of the nation take account of community interests broadly. Several recent examples indicate the persistent need for this contribution to democratic process from civil society. For instance, in 2015, the Coalition Government announced that the board of the National Disability Insurance Agency, which administers the National Disability Insurance Scheme (NDIS), was going to be spilled to make way for greater representation from companies listed on the Australian Securities Exchange (ASX). Representation of the lived experience of people with disabilities, their families, carers and communities was absent from the government's announcement, despite the fact that this was a reform to the governance of one of the most significant social policies of the period, the specific objective of which was to support people with disabilities. In theory, lived experience of disability could be sourced from ASX-listed companies, but Australia's poor performance in employment participation for people with disabilities makes this unlikely (People with Disability Australia 2015). The failure to acknowledge the explicit and important relationship between the NDIS and the people it is intended to support was a clear indictment of institutional power structures that consolidate governance and decision-making away from those most affected by the decisions being made. 
The experience of people who rely on income-support payments has been similarly marginalised by the policymaking processes of successive governments, aided by a willing media. Rhetoric such as 'welfare cheats' and 'lifters versus leaners' is designed particularly to justify harsh welfare measures and budget savings that target people who rely on income support (see, for example, ABC 2015; AFR 2014). This narrative pits the interests of governments who collect tax revenue, or notional 'taxpayers', against people in receipt of working-age payments. This strategy was evident when the same government's 2014 Federal Budget introduced a raft of measures aimed at people relying on income support, such as a six-month waiting period for young people seeking the (working-age payment) Newstart Allowance. ${ }^{2}$ Then treasurer Joe Hockey argued explicitly: 'We must always remember that when one person receives an entitlement from the government, it comes out of the pocket of another Australian' (AFR 2014). Implicit in the government's justification of this measure was a view that young people were too lazy to look for paid work and that working-age payments were largesse the government could not afford. This narrative undermined the legitimate voice of young people in the policy debate. It also ignored the structural challenge of obtaining paid work within a labour market where there was one job available for every five jobseekers (Cox 2014).

The rhetoric of 'encouraging participation' in the workforce has similarly been employed against sole parents, such as when the previous (Labor) government reduced the value of income-support payments to sole parents with children over eight years of age. Efforts to justify budgetary savings measures targeting those on the lowest incomes were framed paternalistically as 'tough love' (Karvelas 2013). In addition to the likelihood of increasing poverty for many sole parents affected, such framing alienated sole parents themselves from the debate, directly undermining their capacity to play an active role in the decision-making about them. These examples show just how easily power can be concentrated to the exclusion of people directly affected by the decisions governments make.

2 The (ultimately unsuccessful) youth measure would have cost young people $\$ 255$ per week for those aged 22-29 years, saving the Federal Budget \$1.253 billion over four years (ACOSS 2014b). 
The role of NFP community organisations advocating for shared power in such decision-making is a key contribution to democratic process. Yet, if we reflect closely on our own practices, we need to acknowledge that the NFP sector does not always model full sharing of power in governance and decision-making itself. In 2012, ACOSS partnered with the Young Women's Christian Association (YWCA) and Women on Boards to run the first survey of gender diversity in leadership positions within Australia's NFP and community sector. In a sector in which almost 80 per cent of the workforce is female (Workplace Gender Equality Agency 2015a), the survey found 60 per cent women to 40 per cent men in the composition of senior management teams (ACOSS et al. 2012b). At one level this compared favourably with relevant benchmarks, such as Australian Bureau of Statistics (ABS) data that showed women held 34.9 per cent of management roles. Yet the healthcare and social assistance sector, which includes the community sector, has consistently shown the largest gender pay gap in Australian industries, of about 30 per cent (Workplace Gender Equality Agency 2015b). While women were doing well in community sector senior management in comparison with other sectors, they were working in a sector that underpaid them. Moreover, 60 per cent representation in senior positions was far from parity in a workforce in which women made up 80 per cent (ACOSS et al. 2012b). Such persistent gender disparity in the leadership of the NFP sector is a sobering reminder of the need to be ever vigilant about how we challenge power and control within our own structures, even as we reflect on the role of the NFP sector in challenging dominant power structures and sharing control in other areas.

\section{Developing a clear shared agenda: Our clarity of purpose}

Harnessing collective power through developing a shared agenda for action is critical to civil society's effectiveness overall. While acknowledging the diversity of perspectives within civil society, there are a number of areas of common interest around which a shared agenda might be constructed. They include:

- the pursuit of equity and justice

- promoting a flourishing democracy

- economic, social and environmental sustainability 
- creating the conditions for living a truly decent human life, with the time and space necessary to make meaningful human connections and contributions within our communities and society.

Identifying common interests is an important start; but the value of a shared agenda requires not just clarity of purpose but also agreement about how we assess our effectiveness in meeting that purpose. We need to measure progress and understand success. Equally importantly, we need to be able to recognise failure and commit to addressing it.

One of the great challenges for NFP organisations in contributing to the project of a shared agenda is the lack of clarity about, and duplication of, decision-making and coordinating mechanisms. The architecture of three layers of government alone creates inconsistency, across federal, state or territory and local government areas; and areas by electorate simply duplicate that inconsistency for the purpose of addressing complex problems. When different bureaucracies at different levels of government use different geographical and spatial areas for efforts to support coordination at the local level, it simply creates barriers for community organisations to try to usefully engage, even where they wish to. For example, the previous federal government's Medicare Locals (MLs) reform did not align with the structure of area health services in New South Wales, and the current federal government's Primary Health Networks (PHNs) have not resolved that lack of alignment. Yet the stated intention of both reforms was precisely to connect federal funding with health policy towards improving primary care through the local provision of health and medical services: the tagline of MLs was 'connecting health to meet local needs' (See, for example, Metro North Brisbane Medicare Local, 2016, mnbml.com.au), while the PHNs are intended to 'increase the efficiency and effectiveness of medical services for patients, particularly those at risk of poor health outcomes ... improving coordination of care to ensure patients receive the right care in the right place at the right time' (Department of Health 2015b).

As civil society continually works to find new ways to come together over shared agendas, Australian governments will come under increasing pressure to agree to the core architecture for local community coordination and planning across their own local, state and territory and federal forms. The lack of such a coordinated approach is a key barrier to the identification of shared agendas to address complex problems, our ability to work collaboratively in the interests of those agendas and our capacity to assess our own effectiveness in meeting them. 


\section{Giving real meaning to collaboration and partnership: The way we work with others}

Complex problems require complex solutions that engage the capacity of both social and economic actors. While no one actor (be they in government, civil society, business or industry) can solve complex problems alone, improved collaboration is essential to maximise the capacity and effectiveness of all sectors working together. At the same time, the disparity in resources available to these different actors is itself a barrier to better collaboration. This is particularly evident within the funding processes for community organisations. Government funding is virtually absent for dedicated, stable community development-related activities such as research, collaboration, design and innovation, policy, advocacy and evaluation. Even as Australia looks to expand philanthropic funding for community organisations, the lessons of the United States - a country with a strong and developed philanthropic culture and sector-tell us that these core capacities are always difficult to fund privately. The sector's fundersboth government and non-governmental-need to recognise that the true value of community organisations in all the ways outlined above needs to be resourced; their effectiveness depends on capacity. Community and economic development-related activities need to be seen as central, not tangential, to the objectives funders are seeking to support when they provide resources to NFPs.

Strikingly, one of the ways we have been best able to understand the importance of the NFP sector's capacity to collaborate, and the value of that collaboration, has been through the application of economic analysis to the work and contribution of the sector. The Productivity Commission's (2010) study of the contribution of Australia's NFP sector was a landmark report in this respect, bringing an economic analysis to the social contribution of the sector. It found that the sector contributed 5 per cent of gross domestic product (GDP) and 8 per cent of employment nationally. The commission found that government funding for services often covered only 70 per cent of the cost of delivering those services, yet this was never explicitly identified by either government or sectoral organisations. Equally significantly, the Productivity Commission demonstrated that the sector's capacity to produce 'spillover' effects beyond the services for which it was specifically funded, such as long-term investment in the communities 
to which it delivered services, constituted a significant part of its value to government and to the community broadly. Even the voices calling for increased competition in community services, such as the Coalition Government-commissioned National Competition Review in 2014, reaffirmed the value provided by community organisations over and above the delivery of specific funded services as a key benefit for government and communities alike that needed to be taken into account in government funding and procurement models (National Competition Review 2014).

A key function provided by Australia's NFP sector is the delivery of social services, and the sector attracts significant levels of government funding to do so. Consequently, the design and delivery of funded programs can be critical to the effectiveness of community services and outcomes for the people being supported. At the Commonwealth level, there are a number of examples of programs that have approached these spillover benefits of community organisations as being central to their value for government funding. The Partners in Recovery program provides coordinated support and flexible funding for 'people with severe and persistent mental illness with complex needs and their carers and families, by getting multiple sectors, services and supports they may come into contact with (and could benefit from) to work in a more collaborative, coordinated and integrated way' (Department of Health 2015a). While evaluation of the program is currently under way, it is a model that reflects one of the core tenets advocated for by the community-based mental health sector: financial incentives to support collaboration and partnership in mental health services (Mental Health Council of Australia 2014).

The Communities for Children (C4C) program is a comparable model, providing prevention and early intervention services to families with children up to the age of twelve. Funded by the Department of Social Services (DSS 2014), the C4C program includes funding for partner programs that 'develop and facilitate a whole of community approach to support and strengthen local service networks that contribute to child safety'. Specifically, the partner programs provide one organisation with the capacity to fund other organisations as part of the integration and coordination of services by community organisations for the communities they support. C4C also funds services that 'provide activities directly to individual services to deliver early intervention and prevention family support, tailored to 
the needs of the local community' (DSS 2014). As an evaluation of the program has found, 'the $\mathrm{C} 4 \mathrm{C}$ model - offering services on a universal basis, an emphasis on partnership and collaboration, flexibility, and an NGO [non-governmental organisation] playing the role of facilitator and coordinator of local services - could have much wider application in the delivery of community services' (Benevolent Society 2009).

Notwithstanding these examples, it is ironic that even as the government-commissioned evidence of the sector's economic contribution through its community value has mounted, government funding processes have undermined that value. In particular, the impact of competitive tendering processes and the rise of the contract state are weakening the very processes of building trust in communities and the collaborative relationships between community organisations through which their spillover value is provided. This is particularly evident within government-funded community services, as organisations compete both for resources and for 'air space' for their particular social purpose. Government-designed open competitive tendering and short procurement processes have driven out capacity for engagement from the local to the national as well as for stable, longer-term community development such as through local planning, delivery and evaluation. Each of these elements works together to address community needs, yet each is also essential to securing durable and effective community leadership and collaboration. While NFP community services seek to work in partnership with governments to achieve these aims, their efforts to do so are frequently frustrated (see further discussion of this in Bletsas 2015).

From 2012 to 2014, the federal government stripped \$1.6 billion in funding from community services across the portfolios of health, social services and attorney-general's and funding for Aboriginal and Torres Strait Islander (ATSI) communities within the Department of the Prime Minister and Cabinet. In the face of these cuts, restructures to funding policy and programs and new competitive tendering processes sought to distribute what funding was left on the basis of priority areas of need. For many in the sector, the results have been disastrous, with a loss of funding without any capacity to plan for transitioning to new funding models. At the same time, under the guise of 'probity', organisations were being told they could not share information about their own funding, and organisations which lost funding were refused information from their funders about who, or whether anyone, had 
picked up funding for the services, areas or populations in which they worked. These conditions fractured, undermined and in some cases destroyed entirely the collaborative relationships community organisations had developed over years - with one another and with the communities in which they worked. Even more significant than the impact of organisations and staff facing closure and job losses, these processes impacted directly on the communities intended to benefit from community service funding.

\section{Case study: Coordinated and integrated services}

AccordWest had been delivering essential support services to some of the most at-risk families, couples and individuals in the south-west of Western Australia for more than 30 years. In 2013-14 they supported more than 18,000 people. After the $\$ 270$ million cut to funding for the Commonwealth DSS, the uncertainty about what if any funding would be delivered meant they lost key staff who were uncertain about their future employment. They were unable to reassure vulnerable clients about the continuity of services they relied on, and their capacity to secure the infrastructure needed to deliver effective services well in the community was reduced (ACOSS 2014a).

The impact of the DSS funding cut included the destruction of community relationships vital to the effectiveness of services for people who depended on them. Equally destructive was the stifling of information about the funding process after this cut-an issue highlighted by a Senate inquiry into the process (Senate Standing Committees on Community Affairs 2015). Analysis of gaps in service provision that guided funding decisions was not released. Departmental policies required confidentiality by organisations including over what funding they had been offered, if any; and in the interests of privacy, the DSS refused to publish information about which organisations had been offered funding and which had not. This stifling of information left community organisations unable to understand the evidence on which funding decisions had been made and with no capacity to advise their clients or communities on what, if any, alternative services would be provided - sometimes for months at a time. An alternative approach - for instance, enabling community organisations to determine for themselves what information they 
would like to share, either with sector colleagues directly or in the public domain - would have significantly reduced the negative impact of the decision to cut funding in the first place.

Undoubtedly, opportunities for effective collaboration between civil society, governments and the market exist and must be strengthened if we are to make gains on the most 'wicked' and entrenched social and economic problems, from lack of affordable housing to long-term unemployment and the social determinants of chronic disease. Improving collaborative processes requires preparedness to accommodate tension and disagreement, but, if achieved, will provide the foundation on which to develop a shared agenda that has the power to effect both vertical and horizontal changes.

In the end, while resourcing for capacity is critical, there are also important questions of principle and design that need to be addressed to ensure strong and effective collaboration. What principles should underpin our collaborative work? Can we collectively push for greater sharing of decision-making and design in our policy, advocacy and service delivery efforts? What would we need to change about ourselves to achieve more collaborative approaches, more effective services and greater local participation in the decisions that affect our communities?

\section{Enabling leadership and participation by those affected by poverty, inequality and injustice: The way we work with those we support}

Recognising that organisations and formal structures represent only one expression of civil society, there is great value in a broad conception of civil society founded on informal relationships, networks, voluntary associations and participation at all levels of the community. Facilitating the exercise of power and agency by the people we serve is crucial to success. Yet there are fears that the marketisation of civil society - that is, as 'consumers' or 'customers' - has led to a weakening of the connection between civil society's institutions and the needs and lived experiences of the individuals and communities we claim to serve. Other fears include the risk that a focus on civil 
society, or even on related notions such as philanthropy, can dilute the critical importance of government providing a social safety net, both in human services (universal in health and education, social services) and in income support. The directions of the 'big society' shift in the United Kingdom and the lack of a social welfare state in the United States both speak to the legitimacy of such concerns.

There are a number of ways civil society can support such leadership and participation:

- By engaging in local, community-focused conversations that connect structural issues with local concerns - for example, as demonstrated by justice reinvestment approaches in Australia and the United States, including in the regional NSW town of Bourke (Just Reinvest NSW 2015) and the US state of Texas (CSG Justice Center 2015).

- By being the change we want to see through our own organisations, including through structuring institutional and governance processes to support the leadership and participation of people directly affected - for example, in disabled people's organisations controlled by a majority of people with disability ( 51 per cent) at the board and membership levels, such as People with Disability Australia.

- By challenging institutional models of local connection and representation, such as through the 'Voices for Indi' movement that ultimately saw an independent elected to a Victorian seat that had been held by the same major party since 1977 (Cassidy 2013).

- By building local advocacy capacity and creating platforms for people affected by the issues to mobilise for change, such as through the 'Places You Love' alliance supporting local community engagement in national policymaking about nature conservation (placesyoulove.org).

To give effect to such aims, we have to relinquish our own power and control and facilitate the leadership and participation of the people with whom we work. But it is important to see these directions as enhancing the effectiveness of democratic decision-making, incorporating as a central component the role of government, particularly in the social safety net. For community organisations particularly, we can drive change in our organisations and our communities through 
our governance, employment and service practices, as well as in our research, policy development and advocacy. In these processes, government is an important, but not the only, object of our efforts.

Two examples of recent work by ACOSS speak to efforts by community NFPs to practise the principles we wish to see demonstrated by others. The first is the leadership of sole parents acting against the cuts to the sole parenting payment introduced by the federal Labor Government in 2012. Sole parents experience some of the most significant poverty and inequality in Australia today. They are highly represented among the more than two million people living in poverty, and their caring responsibilities place them at a significant disadvantage in the labour market. Notwithstanding this vulnerability, the government determined to cut the value of the income-support payments many sole parents relied on by $\$ 56$ per week, as a savings measure worth $\$ 156$ million over four years in the 2011 Federal Budget (ACOSS 2011).

ACOSS opposed this measure and advocated publicly against it, based on detailed analysis of evidence showing it was unlikely to be effective in supporting sole parents into paid work and more likely to increase their experience of poverty. It was, however, the mobilisation of sole parents themselves - a majority of whom are womenthat was a critical element of the strong opposition to the measure. Through representative structures such as the National Council for Single Mothers and their Children (NCSMC) and a range of grassroots organisations comprising people affected by the change, sole parents were a strong voice outlining the impact of this cut and how much it would harm them and their families. ACOSS worked in partnership with its member organisation NCSMC to develop a media and political engagement strategy that combined technical analysis of the policy and its implications with the expertise of lived experience from sole parents, many of whom undertook multiple part-time or casual low-paid jobs and struggled to meet their family expenses. This partnership was critical in ensuring that the voice of people directly affected by federal government policy was heard in the advocacy against that policy. It also seeded other opportunities to maintain the strength of that voice, such as through the '10 Stories' project (10storiesofsinglemothers.org.au/). While the policy was ultimately introduced, the Labor Government subsequently apologised for the measure (Karvelas 2014), recognising it had unfairly and disproportionately impacted on people who could least withstand it. 
Another partnership, between ACOSS and Aboriginal community organisations, has seen the development of a set of principles between Aboriginal and Torres Strait Islander organisations and non-A boriginal community services aimed at supporting Aboriginal community control over the funding and delivery of social services and support in Aboriginal communities (ACOSS 2013). Over successive decades, the level of funding for ATSI people and communities has risen, yet the number of Aboriginal community-controlled organisations has declined in the same period. Non-Aboriginal community services have accepted funding to deliver services to Aboriginal people and in Aboriginal communities, without ensuring Aboriginal control within those services or investing adequately in the capacity of Aboriginal communities to identify their own needs and be resourced to meet them. These Partnership Principles seek a commitment from non-Aboriginal organisations to work in collaborative partnership, not in competition, with ATSI communities and community organisations. Informed by an initial process in the Northern Territory, the development of the national principles was undertaken by the peak organisations for ATSI legal, healthcare, childcare and women's and family violence services and ACOSS. Once the principles were drafted, the lead organisations worked with non-Aboriginal community organisations and NFPs to build commitment to them, and with government in the hopes of affecting decision-making about government funding for Aboriginal communities and services. While there is a long way to go in achieving self-determination by Aboriginal people and communities, the Partnership Principles were an important effort at a sector-led agenda to reverse years of practice by community organisations that had undermined the capacity of Aboriginal people and communities to support themselves strongly and effectively.

\section{Being clear about the roles and responsibilities of civil society, government, the market and business: Creating the solid foundations for our work together}

The role of the market is raising new and important questions about democratic process and the contribution of civil society. These include how the market interacts with NFP organisations and the communities 
they support, and what role, if any, it can usefully play in solving complex social and economic problems. There is strong support in some quarters for market-based financing models that can leverage private funds to achieve positive social outcomes - for instance, through social impact bonds and impact investment. On the other hand, there are legitimate concerns about the long-term impact of such models on the fabric of civil society. We have already seen how the marketisation of human services through competitive tendering can undermine the core value and contribution of community services, particularly where it undermines or fractures the relationships on which that value is based.

Related concerns have also been expressed about the construction of people who rely on human services primarily as 'consumers', particularly people experiencing poverty and inequality, and the natural tendency of market-based mechanisms to cherry-pick profitable services over those that are not, irrespective of need (ACOSS 2014c). As consumer advocate Choice (2015) points out, 'consistent quality and access for Australians should be the priority, and pursuing competition as an end in itself can actually do more harm than good'.

The NDIS is a useful example to think through some of these issues. ${ }^{3}$ The issues paper released as part of the National Competition Review made the following assertions about the NDIS:

Under the National Disability Insurance Scheme (NDIS), Australians with significant and permanent disability will have an individualised plan which sets out their care and support needs and their goals. Providers will be engaged by each individual NDIS participant to deliver support in accordance with the person's plan. Organisations and individuals can apply to be a registered provider and then enter into a written agreement that clearly sets out the support they will provide to an individual. In effect, much of what has been provided by state and territory governments could in future be provided by individuals, non-for-profit organisations and the private sector. (Competition Review 2014: 26 at 4.11)

One of the concerns expressed by civil society is that this competitionbased assessment misrepresents both the policy intent of the NDIS and the practices that are already evident in its implementation. The

3 The following discussion is taken from ACOSS (2014c: 9). 
NDIS does not, nor has it ever been intended to, provide for the sum total of the needs of people living with disability. Income support is one example of a necessary support never intended to be provided through the NDIS. Yet it is a key social support that remains necessary given Australia's continuing failure to include people with disability in the labour market (OECD 2010), which is further evidence that market-based mechanisms cannot meet every need. While it is a significant public policy achievement, it does not, in itself, signal the end of a need for government activity directly, nor for governmentfunded services for people living with disability in Australia.

\section{Case study: ACT Government and the NDIS}

In the Australian Capital Territory, the launch of the NDIS has led to government withdrawing from the provision of services in some areas (specifically early childhood intervention and residential homes). But the ACT Government has now recognised it cannot do that without first developing the markets intended but not yet in existence. It has also recognised a need to continue to provide block funding for tiertwo services that are not commensurate with the individualised funding model and to ensure that those people who are not eligible for the NDIS are still able to access services they need.

By giving participants market-based power as consumers, the policy intention of individualised funding is central to the effort to attract markets into delivering services under the NDIS. But the majority of people living with disability will not be in receipt of individualised funding packages, thereby undermining their ability to access and define the services they want, and creating tensions around resources for service development and delivery. The creation of markets will not solve these tensions and the role of governments as funders will need to continue.

One of the core assumptions of the NDIS is that other human services such as health and education will provide access and support when people within the NDIS use them. Even early in the NDIS trial phase, community organisations have begun reporting that this is not occurring, so some people within its scope are already missing out. Meanwhile, a number of groups, such as people with chronic health needs, are not in scope for the NDIS, yet are unable to access adequate, affordable services within the health system. Thus, while the NDIS 
is an effort to establish a market-based mechanism for vital human services, both its design and its implementation demonstrate some of the pitfalls of assuming market-based mechanisms can meet the full and complex needs of people and communities, particularly those experiencing poverty and inequality.

\section{Conclusion}

Civil society plays a central role in challenging and shifting power and control. Power comes in many forms. The examples discussed cover representative power, decision-making power and reputational power. Another key area of power is knowledge: the power of data to demonstrate particular problems such as unemployment or homelessness; and the power of evidence to support particular solutions for redress such as through improved health and well-being. Governments routinely collect and analyse swathes of data about the people and communities they govern - data that become key tools in decision-making about those communities. Yet communities and the organisations that support them rarely have access to such knowledge or information. This further alienates communities from the decisions that affect them, such as those made by governments.

Governments can and should open up access to data on community and economic well-being-for example, in education, employment, health, housing and social services. Many governments, however, have been reticent to do so. This is despite the clear evidence of the role and value of data as the major driver of technological innovation worldwide, with its multiple uses underpinning everything from scientific research breakthroughs to evolving models of democratic participation and sharing economies. Government reticence to follow suit also shirks a key accountability to the people and communities they serve, which would benefit from the publication of data such as whether and how government policies and services funded by tax revenue are providing adequate and effective support - for instance, in the management of chronic disease or the prevention of poverty.

Domestically, efforts to establish social progress indicators are one example of the role civil society has played in advancing a research agenda that would support greater sharing of power and knowledge. The Australian National Development Index (ANDI) is one such 
example, where academic and other researchers have come together with community and social justice organisations to identify a gap in Australia's evidence base: that while we measure GDP and can demonstrate business confidence, we are poorly equipped when it comes to routine, reliable indicators of social progress or well-being (andi.org.au/what-is-progress). Yet if we are serious about ensuring that our economic progress and growth are inclusive, we need measures of social impact to balance out those of economic impact. The ANDI project is one strategy for filling this void.

In the digital age, the combination of more data being available than ever before and increasingly innovative technological platforms through which those data can be manipulated is significantly changing public expectations of those who hold data and the possibilities of what they do with it. Beyond influencing the public narrative about social progress and well-being, civil society's pursuit of reliable measures to track social progress also opens the way for advocacy to governments and others who collect and hold data about how transparent they are in the data they hold and their willingness to share it. In the United States, the open data debate has focused on the quantity of data collected by agencies across the government, non-governmental and private sectors, and has developed an agenda within which those sectors are expected to make available their data in the interests of transparency and accountability. In Australia, this discussion is still in its infancy, with attention paid mostly to the protection of data in the interests of individual confidentiality. But the driver of transparency and accountability is likely to bring increasing pressure to bear on any and all who hold data, and on how they can produce and disseminate those data for public benefit.

American NFPs have seized the opportunity that access to data provides, as they have steered an agenda towards strong accountability and transparency across their own sector. For NFP and particularly charitable organisations, transparency and accountability are critical to sustaining the support they need to do their work-from funders, donors, volunteers, workers and the beneficiaries of that work.

If we are going to extend the incentives to other organisational forms that ostensibly serve the public good, we should also be sure they are subject to mandatory reporting requirements that will contribute to transparency. Otherwise, we will be left with anecdote, marketing, 
self-reported data and the occasional survey to assess the extent to which they are serving the public good in exchange for the public incentive they receive (Smith 2014).

For some in the sector, transparency and accountability are ends in themselves. The global project of the Open Society Foundations (2015) reflects this, working to build vibrant and tolerant democracies whose governments are accountable to their citizens'. Beyond this focus, the emergence of a range of NFP organisations has provided various platforms from which to analyse charitable data and develop knowledge about the sector as a whole. Transparency and accountability are explicit in the purpose of these organisations, forming the backbone of the research agenda on American NFPs. They also effectively constitute the sector's own research arm, driving and supporting a sector-led agenda of transparency and accountability on which public understanding and support of charities are based.

Through a combination of research organisations and ratings agencies, the US NFP sector has developed a research landscape through which it turns the baseline data collected by charity regulators into a wealth of information and knowledge about itself, and whose role includes the publication and dissemination of this information for public, as well as sectoral, interest.

This spectrum of research organisations enables the sector to set its own agenda of transparency and accountability. Basic information covers the core dimensions of the sector, such as the size and breadth of activity undertaken by US charities, philanthropists and NFPs. There is more detailed information available at both national and local levels, such as how many organisations provide early intervention to children or what kinds of arts organisations are active in any part of the country. The US NFP sector has built highly sophisticated mechanisms to track its activities, from the sources of funding, where they flow and the activities they fund to the dimensions of its workforce and the pay scales of its leadership.

The accountability charities have to the people with whom they work and support may be the most important of all in terms of purpose and impact. Yet it is also the accountability least likely to have structured requirements - and sometimes not even well-defined relationships. Sometimes referred to as a relationship of benefit-as in the 
'beneficiary' of charity - this is regarded by critics as a paternalistic notion reflective of more traditional approaches to charity or philanthropy as an act of giving by those with wealth to those without. Other notions such as capacity building, community development or collective impact seek to shift the power in the relationship away from charitable organisations and towards the people and communities they support. For others still, the language of 'constituencies' is an effort to reflect this more strengths-based approach (see, for example, Smith 2010; ACOSS 2014d).

It matters less how charities and NFPs, or governments, structure their transparency and accountability than that they recognise how central transparency and accountability are to the communities within which they work. As we have seen, sharing power and control not only requires civil society to challenge government practices (or those of business or industry). It also requires courage and preparedness to reflect on the practices of institutions and how they relate to people and communities, to understand the power relationships within Australian society. It requires reflection on our own responsibility for sharing power, and advocacy for the partnerships and other processes through which power can be shared across and beyond governments, business and even NFPs. Civil society organisations can and must play a role in including people who are directly affected by the decisions we make and the services we provide in our decision-making structures, our service design and delivery, the use of information to inform our work and our policy advocacy. In doing so, we can strengthen our effectiveness in shifting power towards the interests of people less powerful in Australian society, both in our external engagement and within our own networks and services.

\section{References}

Australian Broadcasting Corporation (ABC). 2015. 'Senior police officer to lead welfare fraud taskforce to be established by Government.' $A B C$ News, 24 May. Available from: abc.net.au/news/2015-0524/senior-police-officer-to-lead-welfare-fraud-taskforce/6492804 (accessed 1 October 2015). 
Australian Climate Roundtable. 2015. Joint Principles. 29 June. Australian Climate Roundtable. Available from: australian climateroundtable.org.au/ (accessed 1 October 2015).

Australian Council of Social Service (ACOSS). 2011. Federal Budget 2011-2012: Initial ACOSS Analysis. Sydney: ACOSS. Available from: acoss.org.au/wp-content/uploads/2015/06/2011-12_Initial_ Budget_Analysis_final.pdf (accessed 1 October 2015).

Australian Council of Social Service (ACOSS). 2013. Principles for a Partnership-centred approach for NGOs Working with Aboriginal and Torres Strait Islander Organisations and Communities. Sydney: ACOSS. Available from: acoss.org.au/principles-for-a-partnershipcentred-approach/ (accessed 1 October 2015).

Australian Council of Social Service (ACOSS). 2014a. \$1 billion in federal cuts to community services. Briefing Paper. Sydney: ACOSS. Available from: acoss.org.au/images/uploads/ACOSS $\% 20$ Sector $\% 20$ Funding\%20cuts\%20Briefing.pdf (accessed 1 October 2015).

Australian Council of Social Service (ACOSS). 2014b. A Budget that Divides a Nation: ACOSS 2014-15 budget analysis. Sydney: ACOSS. Available from: acoss.org.au/federal-budget-2014-15/ (accessed 1 October 2015).

Australian Council of Social Service (ACOSS). 2014c. Joint COSS Network Submission to Competition Policy Review. Sydney: ACOSS. Available from: acoss.org.au/images/uploads/COSS_Competition_ Review_submission_november_2014.pdf(accessed 1 October 2015).

Australian Council of Social Service (ACOSS). 2014d. Tax Reform for the Common Good. Sydney: ACOSS. Available from: www.acoss. org.au/tax_reform_for_the_common_good/ (accessed 9 February 2015).

Australian Council of Social Service (ACOSS), Australian Council of Trade Unions (ACTU) and Business Council of Australia (BCA). 2012a. Opportunity for all. Joint statement on ACOSS, ACTU and BCA Cooperation. Sydney: ACOSS. Available from: acoss.org. au/media_release/joint_statement_on_acoss_actu_and_bca_ cooperation/ (accessed 1 October 2015). 
Australian Council of Social Service (ACOSS), YWCA Australia and Women on Boards. 2012b. Reflecting Gender Diversity: An analysis of gender diversity in the leadership of the community sector. Sydney: ACOSS. Available from: acoss.org.au/wp-content/ uploads/2015/06/NFP_Boards_and_Gender_Diversity_2012_final. pdf (accessed 1 October 2015).

Australian Financial Review (AFR). 2014. 'Joe Hockey: We are a nation of lifters, not leaners.' Australian Financial Review, 14 May. Available from: afr.com/news/policy/tax/joe-hockey-we-are-anation-of-lifters-not-leaners-20140513-ituma\#ixzz3np2KVzxv (accessed 1 October 2015).

Bletsas, A. 2015. Independence in the not-for-profit sector. A report by ACT Council of Social Services and SA Council of Social Services. ACTCOSS, Canberra. Available from: www.sacoss.org.au/ independence-not-profit-sector (accessed 7 July 2016).

Benevolent Society. 2009. Evaluation of The Benevolent Society's Communities for Children Programs. Sydney: Benevolent Society. Available from: benevolent.org.au/ /media/2B01AA851 B0A8EA2CCE9F9DC0E08EF81.ashx (accessed 1 October 2015).

Cassidy, B. 2013. 'The story of how Cathy McGowan stormed Indi.' $A B C$ News, 13 September. Available from: abc.net.au/news/201309-13/cassidy-indi/4955258 (accessed 1 October 2015).

Choice. 2015. 'Competition Policy Review delivers consumer reforms.' Choice, 2 April. Available from: choice.com.au/shopping/consumerrights-and-advice/your-rights/articles/harper-competition-policyreview-020415 (accessed 1 October 2015).

Competition Review. 2014. Issues Paper. Canberra: Australian Government. Available from: competitionpolicyreview.gov.au/ (accessed 1 October 2015).

Council of State Governments Justice Center (CSG Justice Center). 2015. Collaborative Approaches to Public Safety. Washington, DC: CSG Justice Center. Available from: csgjusticecenter.org/jr/tx/ (accessed 1 October 2015). 
Cox, E. 2014. 'When job seekers outnumber jobs 5 to 1, punitive policy is harmful.' The Conversation, 9 July. Available from: theconversation.com/when-job-seekers-outnumber-jobs-5-to-1punitive-policy-is-harmful-28839 (accessed 1 October 2015).

Department of Health. 2015a. Partners in Recovery. Canberra: Australian Government. Available from: health.gov.au/internet/ main/publishing.nsf/content/mental-pir (accessed l October 2015).

Department of Health. 2015b. Primary Health Networks. Website. Australian Government, Canberra. Available from: health.gov.au/ internet/main/publishing.nsf/content/primary_health_networks (accessed 5 August 2015).

Department of Social Services (DSS). 2014. Communities for Children. Canberra: Australian Government. Available from: dss.gov.au/ our-responsibilities/families-and-children/programs-services/ family-support-program/family-and-children-s-services (accessed 1 October 2015).

Just Reinvest NSW. 2015. JR in Bourke. Sydney: Just Reinvest NSW. Available from: justreinvest.org.au/projects/jr-in-bourke/ (accessed 1 October 2015).

Karvelas, P. 2013. 'Labor's tough love puts 4000 single mothers into work.' The Australian, 10 April. Available from: theaustralian.com. $\mathrm{au} /$ national-affairs/industrial-relations/labors-tough-love-puts4000-single-mothers-into-work/story-fn59noo3-1226616636246 (accessed 1 October 2015).

Karvelas, P. 2014. 'Gillard government "got it wrong" on single parent payments, says Jenny Macklin.' The Australian, 26 March. Available from: theaustralian.com.au/national-affairs/gillard-government-gotit-wrong-on-single-parent-payments-says-jenny-macklin/storyfn59niix-1226864738080 (accessed 1 October 2015).

Mental Health Council of Australia. 2014. Submission to the National Mental Health Commission's Review of Existing Mental Health Programs and Services. Canberra: Mental Health Council of Australia. Available from: mhaustralia.org/sites/default/files/docs/mhca_ submission_to_the_nmhcs_review_of_existing_mental_health_ programs_and_services_june_2014.pdf (accessed 1 October 2015). 
National Competition Review. 2014. Final Report. Canberra: Australian Government. Available from: competitionpolicyreview.gov.au/ (accessed 1 October 2015).

Open Society Foundations. 2015. Website. Open Society Foundations, New York. Available from: opensocietyfoundations.org/about (accessed 8 July 2015).

Organisation for Economic Co-operation and Development (OECD). 2010. Sickness, Disability and Work: Improving social and labourmarket integration of people with disability. Paris: OECD. Available from: oecd.org/els/soc/46488022.pdf (accessed 1 October 2015).

People with Disability Australia. 2015. Get Real on Jobs. Sydney: People with Disability Australia. Available from: pwd.org.au/pwdapublications/get-real-on-jobs2.html (accessed 1 October 2015).

Productivity Commission. 2010. Contribution of the Non-Profit Sector. Canberra: Productivity Commission. Available from: pc.gov.au/ inquiries/completed/not-for-profit/report (accessed 1 October 2015).

Senate Standing Committees on Community Affairs. 2015. Impact on Service Quality, Efficiency and Sustainability of Recent Commonwealth Community Service Tendering Processes by the Department of Social Services. 16 September. Canberra: Australian Government. Available from: aph.gov.au/Parliamentary_Business/Committees/ Senate/Community_Affairs/Grants/Final_Report (accessed 1 October 2015).

Smith, B. 2010. 'Foundations need to be more transparent.' Philantopic, 29 January. Available from: pndblog.typepad.com/ pndblog/2010/01/foundations-need-to-be-more-transparent.html (accessed 20 August 2014).

Smith, B. 2014. Comment by Foundation Center President, Brad Smith, on Lucy Bernholz's blog 'A practical and existential challenge to nonprofits'. Philanthropy 2173: The future of good, 7 May. Available from: philanthropy.blogspot.com/2014/05/a-practicaland-existential-challenge.html (accessed 20 August 2014). 
Workplace Gender Equality Agency. 2015a. Gender Composition of the Workforce: By industry. Sydney: Workplace Gender Equality Agency. Available from: wgea.gov.au/sites/default/files/Gender-compositionof-the-workforce-by-industry.pdf (accessed 1 October 2015).

Workplace Gender Equality Agency. 2015b. Gender Pay Gap Statistics. Sydney: Workplace Gender Equality Agency. Available from: wgea.gov.au/sites/default/files/Gender_Pay_Gap_Factsheet.pdf (accessed 1 October 2015). 
This text is taken from The Three Sector Solution: Delivering public policy in collaboration with not-for-profits and business, edited by John Butcher and David Gilchrist, published 2016 by ANU Press, The Australian National University, Canberra, Australia. 